\title{
TERAPI TRANSFUSI DARAH LEUKODEPLETED PADA PASIEN THALASSEMIA
}

\author{
Bobby Rojas ${ }^{1}$, Irza Wahid ${ }^{2}$ \\ ${ }^{1}$ RSUP Dr. M. Djamil Padang ${ }^{2}$ Subbagian Hematologi Onkologi Medik Bagian Ilmu Penyakit Dalam Fakultas \\ Kedokteran Universitas Andalas, RSUP Dr. M. Djamil Padang \\ email : coboik 06@yahoo.co.id, telp :+6285274597549
}

Submitted: 02-04-2020, Reviewer: 06-04-2020, Accepted: 08-04-2020

\begin{abstract}
Abstrak
Thalassemia merupakan gangguan sintesis hemoglobin $(H b)$, khususnya rantai globin, yang diturunkan. Data Pusat Thalassemia, Departemen Ilmu Kesehatan Anak, FKUI-RSCM, sampai dengan bulan Mei 2014 terdapat 1.723 pasien dengan rentang usia terbanyak antara 11-14 tahun. ${ }^{1,}$ Pengobatan penyakit thalassemia sampai saat ini belum sampai pada tingkat penyembuhan. Di seluruh dunia tata laksana thalassemia bersifat simptomatik berupa transfusi darah seumur hidup. Dahulu target Hb pra transfusi darah $6 \mathrm{gr} \%$ dan pasca transfusi $8-10 \mathrm{gr} \%$, namun sekarang target Hb pra transfusi adalah 9$10 \mathrm{gr} \%$ dan pasca transfusi adalah $12 \mathrm{gr} \%$ pada wanita dan $13 \mathrm{gr} \%$ pada pria. ${ }^{3,4}$ Transfusi darah merupakan tindakan transplantasi organ yang sederhana, tetapi mengandung banyak risiko, seperti reaksi transfusi dan tertularnya penyakit akibat tercemarnya darah donor oleh virus seperti hepatitis $B, C$, Human Immunodeficiency Virus (HIV), dan human t-cell leukemia virus (HTLV). Baru pada akhir tahun 2011 pasien thalassemia di RS tertentu bisa mendapatkan packed red cells (PRC) rendah leukosit dengan menggunakan skrining nucleic acid test (NAT), namun tidak rutin tersedia. Selain risiko tertular penyakit infeksi, pasien yang mendapatkan transfusi berulang juga dapat mengalami reaksi transfusi mulai dari ringan seperti menggigil, urtikaria, sampai berat seperti syok anafilaksis. Penggunaan bedside filter saat pemberian transfusi darah non leukodeplesi pada saat transfusi belum rutin dilakukan, karena akan menambah biaya. ${ }^{1,5,6,7,8}$
\end{abstract}

Kata kunci: Thalassemia, hemoglobin, leukodeplesi

\section{Abstract}

Thalassemia is a hemoglobin $(\mathrm{Hb})$ synthesis disorder, specifically the globin chain, which is inherited. Data Center of Thalasemia, Department of Pediatric, FKUI-RSCM, until May In 2014 there were 1,723 patients with the most age range between 11-14 years old. ${ }^{1,2}$ The treatment of thalassemia until now has not reached the curative level. Around the world, the management of thalassemia is symptomatic in the form of lifelong blood transfusions. Previously the pre blood transfusion $\mathrm{Hb}$ was $6 \mathrm{gr} \%$ and $8-10 \mathrm{gr} \%$ for post transfusion, but now the target of pre transfusion $\mathrm{Hb}$ was 9-10gr\% and post transfusion was $12 \mathrm{gr} \%$ in women and $13 \mathrm{gr} \%$ in men. ${ }^{3,4}$ Blood transfusion is an act of simple organ transplantation, but has many risks, such as transfusion reactions and the transmission of disease due to contamination of blood donor by viruses such as hepatitis B, C, Human Immunodeficiency Virus (HIV), and human t-cell leukemia virus (HTLV). Just the ending of 2011 thalassemia patients in certain hospitals can get low leukocyte packed red cells (PRC) by using nucleic acid test (NAT), but also not routinely available. In addition to the risk of infectious diseases, patients who get repeated transfusions can also experience transfusion reactions ranging from mild such as chills, urticaria, to severe as anaphylactic shock. The use of bedside filters when administering non-leukodepleted blood transfusions at the time of transfusion is also not routinely done, because it will add the cost burden. ${ }^{1,5,6,7,8}$ 
Keywords: Thalassemia, hemoglobin, leukodepleted PENDAHULUAN

Thalassemia merupakan gangguan sintesis hemoglobin $(\mathrm{Hb})$, khususnya rantai globin, yang diturunkan. Penyakit genetik ini memiliki jenis dan frekuensi terbanyak di dunia. Manifestasi klinis yang ditimbulkan bervariasi mulai dari asimtomatik hingga gejala yang berat. Thalassemia dikenal juga dengan anemia mediterania, namun istilah tersebut dinilai kurang tepat karena penyakit ini dapat ditemukan dimana saja di dunia khususnya di beberapa wilayah yang dikenal sebagai sabuk thalassemia. ${ }^{1}$

Pengobatan penyakit thalassemia sampai saat ini belum sampai pada tingkat penyembuhan. Di seluruh dunia tata laksana thalassemia bersifat simptomatik berupa transfusi darah seumur hidup. Transfusi darah yang diberikan pada pasien thalassemia di Indonesia masih PRC non leukodeplesi. 3,4

Kurniawan, dkk (2013) melaporkan bahwa $37,5 \%$ pasien tidak dapat mempertahankan kadar $\mathrm{Hb}$ pasca transfusi dan hal ini berhubungan dengan adanya alloantibodi (78,6\%) dan autoantibodi $(72,7 \%)$, sehingga menyarankan transfusi darah pada pasien thalassemia harus menggunakan darah yang leukodeplesi. ${ }^{9}$ berdasarkan masalah diatas, kami membuat tinjauan pustaka ini untuk membahas bagaimana transfusi yang optimal pada pasien thalassemia.

\section{DEFINISI}

Istilah thalassemia berasal dari kata Yunani yaitu Thalassa (laut) dan Haema (darah) yang mengacu pada adanya gangguan sintesis dari rantai globin (rantai $\alpha$ dan rantai $\beta$ ) yang merupakan subunit dari hemoglobin $\mathrm{Hb} \mathrm{A}(\alpha 2 ; \beta 2)$. Gen untuk sintesis rantai globin terletak di kromosom $11(\beta)$ dan $16(\alpha)$ seperti yang terlihat pada gambar 1. Sindrom Thalasemia diklasifikasikan berdasarkan adanya gangguan dari rantai globin $\alpha$ atau $\beta$. Thalassemia adalah kelainan herediter yang ditandai dengan tidak adekuatnya sintesis dari satu atau lebih rantai dari globin. $1,5,10,11$

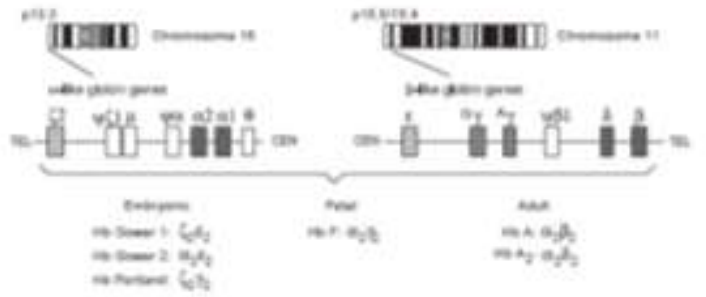

Gambar 1 Struktur rantai gen globin pada kromosom 16 dan $11^{5}$

Hemoglobin merupakan pigmen yang terdapat didalam eritrosit yang terdiri dari heme dan globin dan memiliki berat molekul 64-64.4 kDa. Molekul hemoglobin yang terkandung dalam sel-sel darah merah sangat penting untuk kehidupan manusia. Heme sangat penting untuk transportasi oksigen sedangkan globin berfungsi untuk melindungi heme dari oksidasi. Struktur molekul hemoglobin menghasilkan lingkungan internal hidrofobik yang melindungi besi pada heme dari air, dan juga dari oksidasi. ${ }^{1,4,10,11}$

\section{EPIDEMOLOGI}

Diperkirakan $1,5 \%$ populasi dunia atau sekitar 80-90 juta orang carrier $\beta$ thalassemia, dengan sekitar 60.000 anak lahir pertahun memiliki kasus thalassemia, yang sebagian besar terjadi di dunia yang sedang berkembang. ${ }^{13}$ Hemoglobin E- $\beta$-thalassemia salah satu hemoglobinopati paling sering dijumpai diseluruh dunia. Insiden $\mathrm{HbE}$ banyak terjadi pada 60 populasi di daerah Asia Tenggara. ${ }^{4,11}$ 
Untuk Indonesia sendiri distribusi dan frekuenbsi carriers Thalassemia- $\beta$ di Indonesia ditunjukan pada gambar 2.3, untuk suku minang terlihat ada $4 \%$ dari penduduknya yang merupakan carriers Thalassemia- $\beta$. Di daerah pantai Amerika Utara, prevalensi berkembang pesat. Penyakit $\alpha$ - talasemia sekarang juga sudah banyak dilaporkan. $\mathrm{HbH}, \mathrm{Hb}$ Constants Spring , dan homozigot $\alpha$-thalassemia mempengaruhi sekitar satu juta orang di seluruh dunia. 3\% dari populasi di dunia (sekitar 150 juta orang) memiliki gen carrier $\beta$-thalassemia. ${ }^{4,5,11,12}$

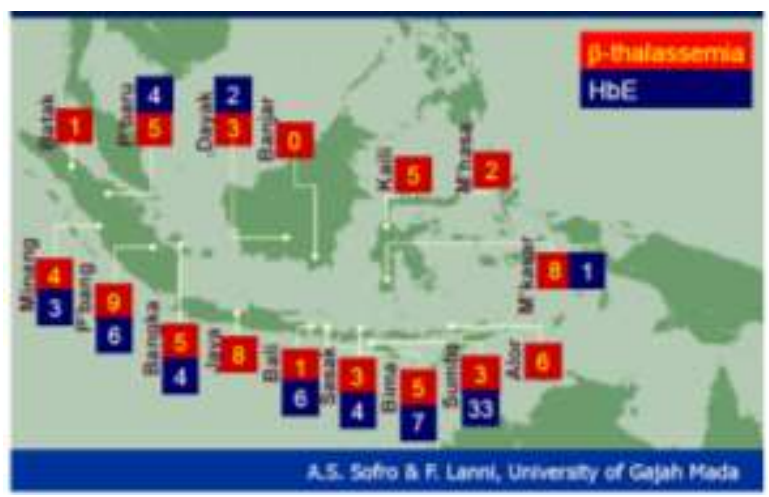

Gambar 2 Distribusi dan frekuensi (\%) carriers Thalassemia- $\beta$ di Indonesia 13

\section{PATOFISIOLOGI}

Patofisiologi yang mendasari antara jenis thalassemia hampir sama, ditandai dengan penurunan produksi hemoglobin dan sel darah merah (RBC), adanya kelebihan rantai globin yang tidak efektif, akan menyebabkan bentuk homotetramers yang tidak stabil, seperti yang terlihat pada gambar 3. Alfa homotetramers pada $\beta$-thalasemia lebih tidak stabil daripada $\beta$-homotetramers di $\alpha$-talasemia dan sebelumnya akan terbentuk presipitasi pada RBC, menyebabkan kerusakan sel darah merah dan hemolisis yang berat oleh karena eritropoesis yang tidak efektif serta hemolisis ekstramedular. ${ }^{14,15} \quad$ Pada $\quad \beta$-thalassemia patofisiologinya berdasarkan karena berkurang atau hilangnya rantai globin- $\beta$ yang akan mengakibatkan berlebihnya rantai- $\alpha$. Maka akan terjadi penurunan produksi hemoglobin dan ketidak seimbangan rantai globin. Ini akan mengarah pada penurunan dari volume hemoglobin $(\mathrm{MCH})$ dan volume eritrosit $(\mathrm{MCV})^{3}$. Pada thalassemia- $\beta$ yang berat, eritropoesis yang tidak efektif terjadi di sumsum tulang akan meluas ke tulang-tulang normal dan menyebabkan distorsi dari tengkorak kepala, tulang wajah dan tulang panjang. Aktivitas proliferasi eritroid di ekstramedular, akan menyebabkan limfadenopati, hepatosplenomegali, dan pada beberapa kasus terjadi tumor ekstramedular. ${ }^{14,15,16}$

Tidak efektifnya eritropoesis yang berat pada anemia kronis dan hipoksia dapat menyebabkan peningkatan absorbsi besi pada saluran pencernaan. Penderita thalassemia homozigot atau pun thalassemia$\beta$ heterozygot akan meninggal pada usia 5 tahun karena anemia yang berat. Namun transfusi menyebabkan penumpukan besi yang progressif oleh karena ekskresi yang tidak baik. ${ }^{16}$

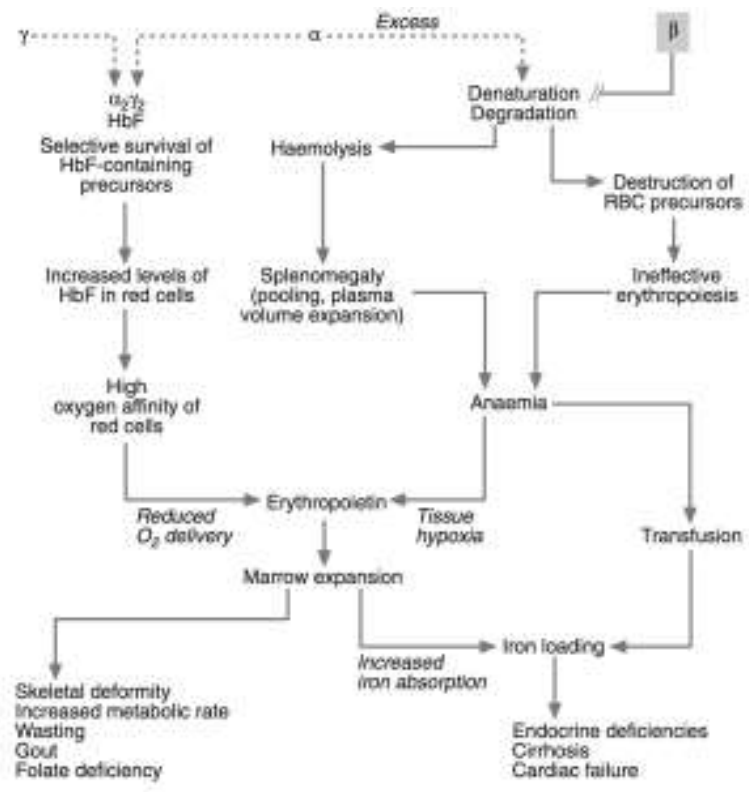

Gambar 3 Patofisiologi Thalassemia ${ }^{14}$

\section{KLASIFIKASI}


Klasifikasi dari Thalassemia berdasarkan jenis subunit globin yang mengalami defek, dan secara garis besar terdiri dari: $1,10,11,15$

\section{Thalas semia- $\alpha$}

Hilangnya produksi gen $\alpha\left(\alpha^{0}\right)$ atau berkurangnya produksi dari gen $\alpha\left(\alpha^{+}\right)$, disebabkan oleh mutasi gen globin $\alpha$ baik berupa delesi gen maupun non-delesi (mutasi titik). Suatu studi molekul yang menggunakan teknik hibrid telah mengidentifikasi hilangnya fungsi gen $\alpha$ yang terkait delesi atau nondelesi dari mutasi gen menyebabkan berkurangnya fungsi gen sehingga menyebabkan mutasi pada kodon yang bertanggung jawab terjadinya syndrom $\alpha$-thalassemia. ${ }^{17,18,19} \quad$ Pada $\alpha$-thalassemia pembagiannya tergantung pada jenis mutasi gen- $\alpha$ yang mengalami kerusakan. Secara klinis thalassemia- $\alpha$ dapat terbagi menjadi 4 kelompok:

\section{a. Silent thalasse mia- $\alpha(-\alpha / \alpha \alpha)$.}

Delesi 1 rantai $\alpha$. Selalu disebut thalassemia- $\alpha^{+}$. Pada keadaan ini tidak terjadi kelainan hematologi. Kelainan ini ditemukan sekitar $15-20 \%$ dari populasi keturunan Afrika.

\section{b. Carrier thalas semia- $\alpha(--/ \alpha \alpha$ atau $-\alpha /-\alpha)$}

Delesi pada 2 gen- $\alpha$. Disebut juga thalassemia- $\alpha$ minor. Dijumpai adanya anemia microcytic hypochromic ringan $(\mathrm{Hb}$ $12.6 \mathrm{~g} / \mathrm{dL}, \mathrm{MCH} 22 \mathrm{pg}, \mathrm{MCV} 68 \mathrm{fL}$ ).

\section{c. Hemoglobin $\mathrm{H}$ disease (--/- $\alpha)$}

Delesi dari 3 gen- $\alpha$. Pengobatan terdiri dari asam folat suplemen $(5 \mathrm{mg} / \mathrm{hari})$ dan transfusi darah. ${ }^{3}$

\section{d. Hydrops Fetalis (--/--)}

Delesi dari ke 4 rantai $\alpha$. Terjadi anemia yang berat, mengalami oedem yang luas, asites, efusi pleura, dan efusi pericardial. ${ }^{8,10}$ Pada pemeriksaan apusan darah tepi banyak dijumpai immature red cell , hipokrom, mikrositer, gambaran sel darah merah anisopoikilos itosis. ${ }^{10}$

\section{Thalass emia- $\beta$}

Terdapat lebih dari 200 mutasi thalassemia- $\beta$ yang telah diakui dan terjadi dalam berbagai kelompok etnis. Thalassemia- $\beta$ umumnya terdapat di daerah Mediterania, di anak benua India di Asia Tenggara dan umumnya pada orang-orang keturunan Afrika. Mutasi thalassemia- $\beta$ dibagi menjadi dua kategori yaitu, Thalassemia- $\beta^{0}$ (beta zero) dan Thalassemia$\beta^{+}$(beta plus). Thalassemia- $\beta$ dapat terjadi oleh karena hilangnya atau berkurangnya produksi dari rantai globin- $\beta$, dapat dibagi menjadi:

\section{a. Thalass emia- $\beta$ minor (trait)}

Pada $\beta$-thalassemia trait kelainan terjadi oleh karena ketidakseimbangan sintesa rantai globin- $\beta$. Pada thalassemia- $\beta$ minor (trait) / tidak mengalami anemia yang berat. Kedua orang tua yang memiliki pembawa sifat $\beta$-thalassemia, maka akan melahirkan ana-anak 25\% normal, 25\% $\beta$ thalassemia mayor dan $50 \% \quad \beta$-thalassemia trait. 19,20

\section{b. Thalass emia- $\beta$ Inte rme dia}

Hampir $10 \%$ pasien thalassemia- $\beta$ mengalami thalassemia- $\beta$ intermedia (TI). Genetik dari kelompok ini mungkin memiliki homozigot talasemia- $\delta \beta$ atau homozygous atau heterozygous thalassemia $\beta^{0}$ dan atau mutasi thalassemia- $\beta^{+}$. Pada beberapa anak $\mathrm{TI}$, walaupun $\mathrm{Hb}>7 \mathrm{~g} / \mathrm{dl}$ dapat mengalami kegagalan dalam pertumbuhan ,kurus yang tidak dapat kembali seperti semula kecuali apabila dilakukan transfusi reguler sebelum umur 6 atau 7 tahun. 19,20,22,23 


\section{c. Thalasse mia Mayor}

Thalassemia- $\beta$ mayor selalu disebut anemia Cooley, anemia Mediterranean dan anemia Jaksch menunjukkan bentuk penyakit yang homozigot ataupun yang heterozigot ditandai dengan gejala anemia berat (1-7 g/dL), hemolisis dan inefektif eritropoesis yang berat. Manifestasi yang muncul pada masa anak-anak dapat terjadi anemia yang berat, ikterus, pertumbuhan terhambat, aktivitas menurun dan sering tidur. Hepatosplenomegali dengan tanda awal dari wajah thalassemia biasanya ditemukan. ${ }^{19}$ Pada pemeriksaan hapusan darah tepi dijumpai poikilositosis, mikrositosis, hipokrom, target sel, basophilic stipling, pappenheimer bodies (siderotic granules) dan retikulositosis dengan peningkatan Nucleated Red cells. ${ }^{19,20,22,24,25}$

\section{DIAGNOSIS}

Dalam mendiagnosis thalassemia sangat penting mengetahui tentang riwayat penderita dan keluarga, karena ada beberapa populasi dengan ras etnik tertentu memiliki frekuensi yang tinggi untuk jenis gen abnormal thalassemia. $1,9,10,11,18$

Pada pemeriksaan fisik penderita thalassemia dapat dijumpai adanya tanda pucat yang menunjukkan adanya anemia, ikterus adanya pembesaran organ seperti splenomegali, hepatomegali, dan skeletal formation. ${ }^{1,9,10,11}$

Pemeriksaan laboratorium meliputi, pemeriksaan darah lengkap (complete blood count/CBC), khususnya memeriksa nilai eritrosit rerata seperti Mean Corpuscular Volume (MCV), Mean corpuscular hemoglobin (MCH), Mean Corpuscular Hemoglobin Concentration (MCHC), Red Blood Cell Distribution Width (RDW). Pada pasien thalassemia- $\alpha$ maupun thalassemia- $\beta$ menunjukan nilai $\mathrm{MCV}$ dan $\mathrm{MCH}$ yang rendah (Mikrositer hipokrom) dan mengalami anemia. Pada kasus $\beta$ thalassemia trait mengalami anemia yang ringan. ${ }^{11,12}$ Pemeriksaan laboratorium pada thalassemia diperlukan juga evaluasi sediaan hapusan darah tepi, badan inklusi $\mathrm{HbH}$ serta analisa hemoglobin dengan pemeriksaan hemoglobin elektroforesis dengan menilai kadar HbA2 dan kadar HbF. Kuantitasi $\mathrm{HbA} 2$ yang meningkat $>3,5 \%$ mengidentifikasi suatu $\beta$-thalassemia trait. Analisa hemoglobin selain hemoglobin elektroforesis yaitu dengan menggunakan HPLC. Mutasi yang terjadi sehingga mengakibatkan diagnosis negatif palsu, maka pemeriksaan analisa genetik sangat diperlukan. ${ }^{10,11,12}$

\section{TRANSFUSI DARAH}

Tujuan transfusi darah pada pasien thalassemia adalah untuk menekan hematopoiesis ekstramedular dan mengoptimalkan tumbuh kembang anak. Keputusan untuk memulai transfusi darah sangat individual pada setiap pasien. Transfusi dilakukan apabila dari pemeriksaan laboratorium terbukti pasien menderita thalassemia mayor, atau apabila $\mathrm{Hb}<7 \mathrm{~g} / \mathrm{dL}$ setelah $2 \mathrm{x}$ pemeriksaan dengan selang waktu $>2$ minggu, tanpa adanya tanda infeksi atau didapatkan nilai $\mathrm{Hb}>7 \mathrm{gr} / \mathrm{dL}$ dan dijumpai, gagal tumbuh, dan/atau deformitas tulang akibat thalassemia. ${ }^{11}$

\section{Evaluasi sebelum transfusi}

Pasien perlu menjalani pemeriksaan laboratorium berikut sebelum memulai transfusi pertama: $11,21,22$

a. Profil besi : feritin serum, serum iron (SI), total iron binding capacity (TIBC)

b. Fungsi hati : SGOT, SGPT, PT, APTT, albumin, bilirubin indirek, dan bilirubin direk.

c. Fungsi ginjal : ureum, kreatinin 
d. Golongan darah: ABO, Rhesus

e. Marker virus yang dapat ditransmisikan melalui transfusi darah: antigen permukaan Hepatitis B (HbsAg), antibodi Hepatitis C (anti-HCV), dan antibodi HIV (anti-HIV).

\section{f. Bone age.}

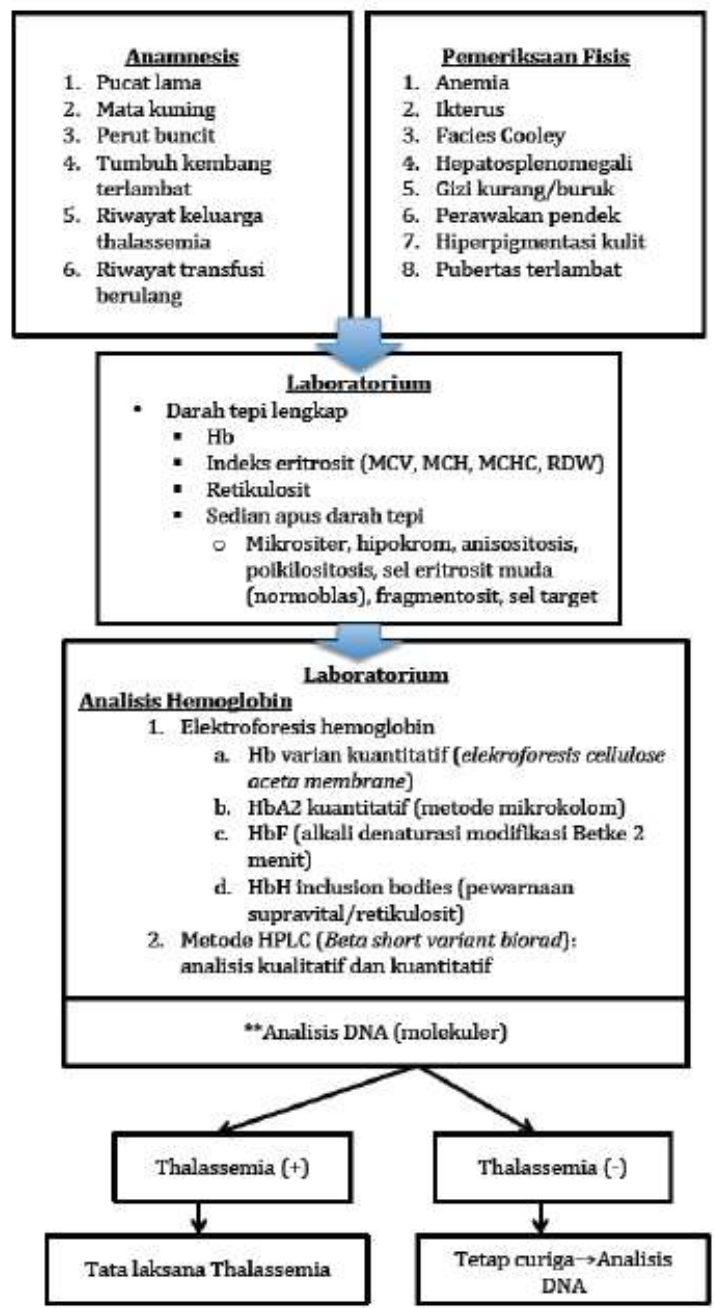

Gambar 4 Alur diagnosis thalassemia 11

\section{Cara pemberian transfusi darah $21,22,25$}

a) Volume darah yang ditransfusikan bergantung dari nilai $\mathrm{Hb}$. Bila kadar $\mathrm{Hb}$ pratransfusi $>6 \mathrm{gr} / \mathrm{dL}$, volume darah yang ditransfusikan berkisar $10-15 \mathrm{~mL} / \mathrm{kg} / \mathrm{kali}$ dengan kecepatan 5 $\mathrm{mL} / \mathrm{kg} / \mathrm{jam}$.

b) Target pra kadar $\mathrm{Hb}$ post-transfusi tidak melebihi dari 14-15 g/dL, sedangkan kadar $\mathrm{Hb}$ pratransfusi berikutnya diharapkan tidak kurang dari $9,5 \mathrm{mg} / \mathrm{dL}$. Nilai $\mathrm{Hb}$ pretransfusi antara 9-10 $\mathrm{g} / \mathrm{dL}$ dapat mencegah terjadinya hemopoesis ekstramedular, menekan konsumsi darah berlebih, dan mengurangi absorpsi besi dari saluran cerna.

c) Jika nilai $\mathrm{Hb}<6$ gr/dL, dan atau kadar $\mathrm{Hb}$ berapapun tetapi dijumpai klinis gagal jantung maka volume darah yang ditransfusikan dikurangi menjadi 2-5 ml/kg/kali dan kecepatan transfusi dikurangi hingga $2 \mathrm{~mL} / \mathrm{kg}$ per jam untuk menghindari kelebihan cairan/overload.

d) Darah yang diberikan adalah golongan darah donor yang sama $(\mathrm{ABO}, \mathrm{Rh})$ untuk meminimalkan alloimunisasi dan jika memungkinkan menggunakan darah leucodepleted yang telah menjalani uji skrining nucleic acid testing (NAT) untuk menghindari/meminimalkan

tertularnya penyakit infeksi lewat transfusi.

e) Darah yang sudah keluar dari bank darah sudah harus ditransfusikan dalam waktu 30 menit sejak keluar dari bank darah. Lama waktu sejak darah dikeluarkan dari bank darah hingga selesai ditransfusikan ke tubuh pasien maksimal dalam 4 jam. Transfusi darah dapat dilakukan lebih cepat (durasi 2-3 jam) pada pasien dengan kadar $\mathrm{Hb}>6 \mathrm{gr} / \mathrm{dL}$.

f) Nilai $\mathrm{Hb}$ dinaikan secara berlahan hingga target $\mathrm{Hb} 9 \mathrm{gr} / \mathrm{dL}$. Diuretik furosemid dipertimbangkan dengan dosis 1 hingga $2 \mathrm{mg} / \mathrm{kg}$ pada pasien dengan masalah gangguan fungsi jantung atau bila terdapat klinis gagal jantung. Pasien dengan masalah jantung, kadar $\mathrm{Hb}$ pratransfusi 
dipertahankan 10-12 g/dL. Pemberian transfusi diberikan dalam jumlah kecil tiap satu hingga dua minggu.

g) Interval antar serial transfusi adalah 12 jam, namun pada kondisi anemia berat interval transfusi berikutnya dapat diperpendek menjadi 8-12 jam.

h) Setiap kali kunjungan berat badan pasien dan kadar $\mathrm{Hb}$ dicatat, begitu pula dengan volume darah yang sudah ditransfusikan. Data ini dievaluasi berkala untuk menentukan kebutuhan transfusi pasien. Pasien tanpa hipersplenisme kebutuhan transfusi berada di bawah $200 \mathrm{~mL}$ $\mathrm{PRC} / \mathrm{kg}$ per tahun. Prosedur transfusi mengikuti/sesuai dengan panduan klinis dan laboratoris masing-masing senter. Pada saat transfusi, diperhatikan reaksi transfusi yang timbul dan kemungkinan terjadi reaksi hemolitik. Pemberian asetaminofen dan difenhidramin tidak terbukti mengurangi kemungkinan reaksi transfusi.

\section{Jenis produk darah yang digunakan}

Idealnya darah yang ditransfusikan tidak menyebabkan risiko atau efek samping bagi pasien. Beberapa usaha mulai dari seleksi donor, pemeriksaan golongan darah, skrining darah terhadap infeksi menular lewat transfusi darah (IMLTD), uji silang serasi (crossmatch), dan pengolahan komponen telah dilakukan untuk menyiapkan darah yang aman. Beberapa teknik pengolahan komponen darah sudah dapat dilakukan untuk meningkatkan keamanan darah. Tersedianya komponen darah yang aman akan menunjang pemberian transfusi darah secara rasional dan berdasarkan indikasi yang tepat. ${ }^{22,23}$
Beberapa produk darah dapat dijumpai di bank darah, salah satunya adalah eritrosit cuci/ washed erythrocyte (WE). Produk ini memberikan beberapa keuntungan antara lain dapat menghilangkan leukosit 5095\% dan eritrosit $15 \%$. Komponen darah WE dapat mengurangi risiko terjadinya reaksi alergi, dan mencegah reaksi anafilaksis pada defisiensi IgA. Kerugian WE ini memiliki waktu simpan yang pendek 4-6 jam dan memiliki risiko bahaya kontaminasi. Produk ini tidak direkomendasikan pada thalassemia. $22,23,26,27$

Sekitar tahun 1860-1970 mulai dikembangkan tehnik leukodepleted, yaitu berupa proses pemisahan buffy coat (BC) yang mengandung leukosit dan trombosit dari PRC dengan sedimentasi atau sentrifugasi sehingga leukosit menurun 60$80 \%$ dan eritrosit menurun $20-30 \%$. Teknik ini terbukti dapat mencegah dan mengurangi dampak kontaminasi leukosit. Beberapa terminologi dapat dijumpai di literatur adalah leukodepleted di Eropa dan leucoreduced di US. Perbedaannya terletak pada jumlah leukosit yang dapat disaring, yaitu leukodepleted dapat mengurangi leukosit hingga $10^{7}-10^{8}$, sedangkan leucoreduced < $10^{5}$. Sedangkan jumlah leukosit pada 1 unit whole blood (WB) adalah $2 \times 10^{9} .{ }^{26,28}$

Proses pemisahan leukosit pada komponen darah menggunakan filter yang terbuat dari bahan tertentu yang dapat memisahkan leukosit. Proses ini dapat dilakukan pada saat pembuatan darah/ pra-storage atau beberapa saat sebelum transfusi/post-storage. Jenis darah PRC biasa dan WE tetap membutuhkan bed side filter. ${ }^{29}$

\section{TRANFUSI LEUKOREDUCTION}

Proses ini juga dikenal sebagai leukofiltrasi dan berdasarkan standar AABB ( American Association of Blood Banks) ada tiga standar leukoreduction :26,27,28 
1. Leukocyte-reduced RBCs :
a. Masih ada setidaknya $85 \%$ dari sel darah merah asli
b. $\quad<5 \times 10^{6}$ sel darah putih

2. Leukocyte-reduced Platelet Concentrates:
a. Paling sedikit ada 5,5 x $10^{10}$ trombosit
b. $\quad<8,3 \times 10^{5}$ sel darah putih
c. $\quad \mathrm{pH} \geq 6,2$

3. Leukocyte-reduced Apheresis Platelets ::
a. Paling sedikit ada $3,0 \mathrm{x}$ $10^{11}$ trombosit
b. $\quad<5,0 \times 10^{6}$ sel darah putih
c. $\quad \mathrm{pH} \geq 6,2$

\section{Jenis Leukoreduction $^{29}$}

1. Pre-storage
a. Dilakukan dalam 24 jam pengumpulan
b. Dapat menggunakan inline filters pada saat pengumpulan (apheresis) atau setelah pengumpulan

\section{Leukoreduction "Pra-transfusi" / bedside leukoreduction}
a. Dilakukan sebelum transfusi.
b. Leukoreduction "Bedside" menggunakan filter berbasis gravitasi pada saat transfusi.
c. Alternatifnya dilakukan oleh layanan transfusi.

\section{Transfusi Leukoreduction pada Thalass emia}

Transfusi darah selalu dikaitkan dengan sejumlah hasil buruk yang terus menurun selama bertahun-tahun karena penemuan baru dan kemajuan teknis. Pasien thalassemia lebih rentan terhadap komplikasi terkait transfusi karena transfusi berulang. Mempelajari reaksi-reaksi ini dan menghubungkannya dengan status leucodepletion dari sel darah merah yang ditransfusikan (PRBCs) dapat mengurangi komplikasi transfusi karena leukosit yang ditransfusikan. ${ }^{26,28}$

Dengan munculnya terapi transfusi, thalassemia bukan lagi penyakit fatal pada masa kanak-kanak tetapi penyakit kronis yang kompatibel dengan masa hidup yang panjang. Di sisi lain, transfusi darah sering menyebabkan reaksi transfusi, infeksi yang ditularkan melalui transfusi, kelebihan zat besi, dan sifat kronis dari penyakit ini telah berkontribusi pada spektrum komplikasi yang sama sekali baru. Beberapa komplikasi ini muncul karena mekanisme yang dimediasi imun yang melibatkan sel darah putih dari donor. Dengan demikian, eliminasi sel darah putih dari sel donor menghasilkan pengurangan reaksi yang merugikan tersebut. Berbagai metode leucoreduction telah berhasil digunakan di masa lalu dan terbukti mengurangi reaksi febrile nonhemolytic transfusion reactions. ${ }^{27,28,29}$

Thalassemia mayor membutuhkan transfusi secara teratur sehingga perlu diperhatikan hal-hal di bawah ini :27,28,29,30

a) Produk darah yang digunakan hendaknya PRC rendah leukosit (leukodepleted) yang telah menjalani uji skrining NAT dan menggunakan produk darah yang telah dicocokkan dengan darah pasien.

b) Penggunaan pre-storage filtration terbukti lebih baik dibandingkan dengan bed side filtration. Pada pre-storage filtration, leukosit akan difilter sebelum sempat mengeluarkan sitokin, sehingga reaksi transfusi berupa febrile non hemolytic transfusion reaction (FNHTR) dapat lebih dihindari, yang penyebabnya selain alloimunisasi oleh human 
leukocyte antigen (HLA) juga karena keberadaan sitokin dalam komponen darah.

c) Penggunaan whole blood pada pasien dengan transfusi rutin dapat menyebabkan reaksi transfusi nonhemolitik.

d) Apabila darah leukodepleted dengan skrining NAT tidak tersedia dapat dipertimbangkan darah yang berasal dari donor tetap untuk mengurangi risiko penyakit yang ditransmisikan melalui darah, alloimunisasi, dan reaksi transfusi lainnya.

e) Komplikasi dari transfusi dapat dikurangi dengan pemilihan produk darah tertentu seperti PRC cuci, sel darah merah beku/ frozen (cryopreserved red cells), dan donor tetap, walaupun pada thalassemia yang membutuhkan transfusi darah berulang idealnya mendapatkan PRC leukodepleted.

Dalam penelitian Neeti Dutt, et al (2017), febrile nonhemolytic transfusion reactions terjadi pada $0,97 \%$ dari total transfusi dan pada 8,69\% $(\mathrm{n}=12)$ dari total pasien. Ketika bedside filter digunakan, reaksi terjadi adalah $0,8 \%$ dan ketika darah leucoreduced buffy-coat digunakan, reaksi terjadi menjadi $0,16 \%$. Ketika bedside filter dan darah leucoreduced digunakan, tidak ada reaksi yang didokumentasikan. Di sisi lain, penggunaan darah tidak leucoreduced mengakibatkan terjadinya febrile nonhemolytic transfusion reactions sebesar $4,1 \%$. Ini menunjukkan bahwa pengurangan yang sangat signifikan terjadi pada febrile nonhemolytic transfusion reactions ketika darah leucoreduced buffy-coat ditransfusikan dibandingkan dengan darah yang tidak leucoreduced ( $\mathrm{p}<0,0001)$. Namun, tidak ada pengurangan yang signifikan $(\mathrm{p}=0,06)$ dalam febrile nonhemolytic transfusion reactions antara bedside filter dan darah yang tidak leukoreduced. Dalam penelitian ini, sebagian besar febrile nonhemolytic transfusion reactions terjadi pada pasien yang menerima darah non - leucoreduced yaitu $82,3 \%$ ( $\mathrm{n}=14)$ dan ada pengurangan yang signifikan dalam reaksi transfusi ini pada pasien yang menerima darah leucodepleted yaitu $17,6 \%(\mathrm{n}=3)$ dengan $\mathrm{p}$ $<0,0001 .{ }^{26}$

Menurut Devi AMS et al (2014) reaksi transfusi terjadi sekitar $0,22 \%$ ketika darah yang leucoreduced digunakan dan $0,58 \%$ ketika darah yang tidak leucoreduced digunakan. Tingkat reaksi adalah nol ketika filter bedside digunakan dalam penelitian mereka. ${ }^{28}$ Demikian pula dalam penelitian Tan et al (1993) melaporkan tingkat reaksi transfusi pada 26 anak-anak thalasemia yang telah menerima 211 transfusi darah selama periode 6 bulan. Reaksi transfusi berkurang secara signifikan pada kelompok yang menerima darah yang disaring $(\mathrm{P}<0,05) .{ }^{32}$ Dalam penelitian lain yang dilakukan oleh Karen E et al (2004) yang membandingkan hasil kejadian FNHTRs selama dua periode waktu setelah pengenalan darah leucoreduced menemukan bahwa ada perbedaan signifikan dalam kejadian FNHTR yang terlihat antara dua periode $(0,37 \%$ pada tahun 1994 vs 0,19\% pada tahun 2001, p = 0,0008). ${ }^{29}$ Kumar $\mathrm{H}$ et al (2006) juga menunjukkan bahwa setelah pengenalan darah leucodepletion untuk thalassemia di center mereka, kejadian febrile nonhaemolytic transfusion reactions (FNHTR) turun dari 4\% pada tahun 2002 menjadi 1\% pada tahun 2003. Pengurangan FNHTRs ini adalah salah satu dari beberapa argumen yang mendukung penggunaan komponen darah leukoreduction. ${ }^{30}$

\section{Reaksi transfusi dan tata laksananya}


Bila terjadi reaksi transfusi, tata laksana disesuaikan berdasarkan berat ringannya reaksi transfusi. Penggunaan PRC leukodepleted dapat mengurangi berbagai reaksi transfusi sedangkan penggunaan premedikasi seperti asetaminofen dan difenhidramin tidak terbukti mengurangi risiko reaksi transfusi. ${ }^{9,1326}$

\section{a. Demam sebagai reaksi transfusi non- hemolitik (febrile nonhemolytic transfusion reactions/FNHTR)}

Reaksi transfusi ini sering terjadi beberapa dekade lalu, namun dengan penggunaan PRC leukodepleted kejadiannya semakin jarang. Kejadian ini dipicu oleh akumulasi sitokin dan alloimunisasi. Demam juga dapat disebabkan oleh reaksi hemolitik akibat dari produk darah yang terkontaminasi bakteri. ${ }^{26}$

\section{b. Reaksi alergi}

Reaksi alergi dimediasi oleh IgE, biasanya dipicu oleh protein plasma, dan dapat bermanifestasi ringan hingga berat. Reaksi ringan seperti urtikaria, gatal, dan ruam kemerahan, sedangkan gejala yang berat meliputi stridor, bronkospasme, hipotensi, hingga reaksi anafilaksis. Reaksi alergi berat terutama diwaspadai pada pasien dengan imunodefisiensi IgA dan pasien yang memiliki antibodi IgA. Pencegahan reaksi alergi berulang dapat dilakukan dengan pemberian PRC cuci. Pasien dengan defisiensi $\operatorname{IgA}$ dapat diberikan darah dari donor dengan defisiensi IgA. ${ }^{26}$

\section{c. Reaksi hemolitik}

Reaksi hemolitik akut dapat terjadi dalam hitungan menit sampai beberapa jam setelah transfusi. Gejala yang ditimbulkan adalah demam mendadak, menggigil, nyeri tulang belakang, sesak, hemoglobinuria, dan syok. Reaksi ini dapat timbul karena produk darah yang diberikan tidak sesuai dengan darah pasien. Ketidaksesuaian produk darah ini lebih banyak terjadi pada pasien yang melakukan transfusi di tempat yang tidak biasanya. Kesalahan ini dapat dikurangi dengan mengidentifikasi pasien dengan cermat sebelum memberikan darah. Idealnya pemeriksaan label darah dilakukan oleh 2 staf yang berbeda sebelum memberikan produk darah. Apabila dicurigai terjadi reaksi transfusi, hentikan transfusi segera, dan berikan cairan intravena untuk mempertahankan volume intravaskular. Pemberian diuretik dipertimbangkan dalam kondisi terjadi penurunan fungsi ginjal. Apabila terjadi koagulasi intravaskular diseminata (KID) dapat diberikan heparin. Identitas donor dan penerima darah diperiksa ulang dan bank darah harus mencari kemungkinan adanya alloantibodi yang tidak terdeteksi. ${ }^{26,27}$

Reaksi lambat terjadi dalam 5 hingga 14 hari setelah transfusi, ditandai dengan anemia yang terjadi tiba-tiba, ikterik, dan malaise. Reaksi ini terjadi apabila alloantibodi tidak terdeteksi pada saat transfusi dilakukan atau terdapat pembentukan antibodi baru. Apabila hal ini terjadi contoh darah dikirim ke PMI untuk dilakukan pemeriksaan lebih lanjut. ${ }^{26,27,28}$

\section{d. Anemia hemolitik autoimun}

Anemia hemolitik autoimun adalah komplikasi serius akibat transfusi darah. Darah yang diberikan mungkin kompatibel pada pemeriksaan awal, namun umur eritrosit sangat pendek dan kadar $\mathrm{Hb}$ turun di bawah kadar $\mathrm{Hb}$ pratransfusi biasanya. Destruksi darah terjadi pada darah pasien dan donor serta evaluasi serologi menunjukkan reaksi antigen-antibodi luas. Kondisi ini dapat diatasi dengan pemberian steroid, agen imunosupresan, dan imunoglobulin intravena. Kejadian ini umumnya terjadi pada transfusi pada usia dewasa. ${ }^{26}$

\section{e. Transfusion-related acute lung injury}


Transfusion-related acute lung injury

(TRALI) adalah komplikasi berat yang mungkin terjadi akibat anti-neutrofil atau antibodi anti-HLA. Komplikasi ini ditandai oleh dispnu, takikardia, demam, dan hipotensi dalam jangka waktu 6 jam setelah transfusi. Pemeriksaan foto toraks dapat memperlihatkan infiltrat di seluruh lapang paru atau gambaran edema paru. Tata laksana TRALI bersifat suportif meliputi pemberian oksigen, steroid, diuretik, dan pada kondisi yang berat dapat diperlukan ventilasi mekanik. ${ }^{26,27,28}$

\section{f. Transfusion-induced graft-versus-host disease}

Transfusion-induced graft-versushost disease (TI-GVHD) disebabkan oleh limfosit hidup yang berada dalam darah donor. Kondisi ini jarang terjadi dan bersifat fatal. Risiko mengalami TI-GVHD lebih tinggi pada pasien imunokompromais, atau pasien imunokompeten yang mendapatkan darah dari anggota keluarga yang memiliki TI-GVHD. Reaksi terjadi dalam 1 hingga 4 minggu setelah transfusi, ditandai dengan demam, ruam, disfungsi hati, diare, dan pansitopenia akibat kegagalan sumsum tulang. Untuk mengurangi risiko TI-GVHD hindari transfusi dari anggota keluarga/ donor haploidentikal. Transfusi menggunakan leucodepleted saja tidak mengurangi risiko ini. ${ }^{9,1126}$

\section{g. Transfusion-associated circulatory overload}

Transfusion-associated circulatory overload (TACO) terjadi pada kondisi disfungsi jantung atau pada pemberian transfusi yang terlalu cepat. Reaksi ditandai dengan sesak dan takikardia, sedangkan foto toraks menunjukan edema pulmonal. Tata laksana ditujukan untuk mengurangi volume darah dan meningkatkan fungsi jantung. Pertimbangkan penggunaan oksigen, diuretik, dan obat gagal jantung bila diperlukan. ${ }^{26}$

\section{h. Transmisiagen infeksius}

Transfusi darah dapat mentransmisikan agen infeksius seperti bakteri, virus, dan parasit. Hal ini masih dapat terjadi karena beberapa kemungkinan berikut:

a. Jenis dan jumlah pemeriksaan untuk mendeteksi patogen masih terbatas. Masih banyak skrining patogen yang belum dapat dilakukan.

b. Transmisi virus masih dapat terjadi karena masih dalam window period dan beberapa alat tes yang ada tidak spesifik.

c. Munculnya agen infeksius baru.

\section{Daftar Pustaka}

1. Weatherall D. Thalassaemia : The Biography (Biographies of disease). 1st ed. Oxford University Press; 2010. 6-24.

2. Wahidiyat $\mathrm{P}$, Gatot $\mathrm{D}$, Tjitrasari $\mathrm{T}$, Ringoringo $\mathrm{H}$, Marzuki N, Taufani R, et al. Phenotypic diversity in beta-HbE thalassemia patients. Paediatr Indones. 2006;49(3-4):82

3. Chow KU, Seifried E, Bonig H. Spleen size Is significantly influenced by body height and sex: establishment of normal values for spleen size at US with a Cohort of 1200 healthy individuals. Radiology. 2016;279(1).

4. Saragih EYP. Target Pencapaian Kadar Hemoglobin Pra dan Pasca Transfusi Darah Pasien Dewasa Thalassemia Beta Tergantung Transfusi : Faktor - faktor Risiko dan Hubungannya dengan Ukuran Limpa. Jakarta. 2019.

5. Modell C, Berdoukas V. The Clinical Approach to Thalassaemia. New York: Grune \& Stratton; 1984.

6. Merianou V, Panousopoulou L, Lowes L, Pelegrinis E, Karaklis A. 
Alloimmunization to red cell antigens in thalassemia: comparative study of usual versus better-match transfusion programmes. Vox Sang. 1987;52(12):95-8.

7. Modell B, Khan M, Darlison M. Survival in beta-thalassaemia major in the UK: data from the UK Thalassaemia Register. Lancet. 2000;355(9220):2051-2. Patel AS, Gamit S, Gohil M. Role of RBC's alloimmunization in multiple transfused thalassaemia patients. Int J Res Med Sci Int J Res Med Sci. 2016;44(3):822-8.

8. Chandra Sharma D, Singhal S, Woike P, Rawat N, Arya A, Gaur R. Red Blood Cells Alloimmunization and Transfusion Strategy in Transfusion Dependent BThalassemia Patients. IOSR J Dent Med Sci. 2016;15:2279-861.

9. Kurniawan A, Atmakusuma D, Sukrisman L. Erythrocyte alloantibody in transfusion dependent thalassemia patients: Proportion and related factors. transfus med hemother. 2013;40:40. Cohen AR, Glimm E, Porter JB, Dc W. Effect of transfusional iron intake on response to chelation therapy in Effect of transfusional iron intake on response to chelation therapy in beta-thalassemia major. Blood. 2008;111(2):583-7.

10. Weatherall D. The thallasaemia syndromes. 4th ed. Gibbons R, editor. London: Blackwell Science; 2001.

11. Atmakusuma D. Thalassemia : Manifestasi klinis, pendekatan diagnosis, dan Thalassemia Intermedia. Buku Ajar Ilmu Penyakit Dalam. 2014. Jakarta:2632-38.

12. Yataganas X, Gahrton G, Thorell B. Intranuclear hemoglobin In erythroblast of B-thalassemia. Blood. 2017;43(2):243-51.
13. Yang JC, Rickman LS, Bosser SK. The clinical diagnosis of splenomegaly. West J Med. 1991;155(1):47-52.

14. Pivkin I V, Peng Z, Karniadakis GE, Buffet PA, Dao M, Suresh S. Biomechanics of red blood cells in human spleen and consequences for physiology and disease. Proc Natl Acad Sci. 2016;113(28):7804-9.

15. Merchant RH, Shah AR, Ahmad J, Karnik A, Rai N. Post splenectomy outcome in $\beta$-thalassemia. Indian $\mathbf{J}$ Pediatr. 2015;82(12):1097-100.

16. Cohen AR, Glimm E, Porter JB, Dc W. Effect of transfusional iron intake on response to chelation therapy in Effect of transfusional iron intake on response to chelation therapy in beta-thalassemia major. Blood. 2008;111(2):583-7.

17. Capellini M, Grespi E, Cassinerio E, Bignamini D, Fiorelli G. Coagulation and splenectomy: an overview. Ann N Y Acad Sci. 2005;1054(1):317-24.

18. Stewart R. K, Derck M. A, Long L. K, Learman K, Cook C. Diagnostic accuracy of clinical tests for the detection of splenomegaly. Phys Ther Rev. 2013;18(3):173-84.

19. Tamayo S, Rickman L, Mathews W, Fullerton S, Bartok A, Warner J, et al. Examiner dependence on physical diagnostic tests for the detection of splenomegaly: a prospective study with multiple observers. J Gen Intern Med. 1993;8(2):69-75.

20. Premawardhena A, Arambepola M. Is the b thalassaemia trait of clinical importance ? BJH. 2008;141:407-10.

21. Elzik ME, Dirschl DR, Dahners LE. Correlation of transfusion volume to change in hematocrit. Am $\mathrm{J}$ Hematol. 2006;81(2):145-6.

22. Cable R, Carlson B, Chambers L, Kolins J, Murphy S, Tilzer L, et al. Practice 
guidelines for blood transfusion.

2007;64.

23. Davies P, Robertson S, Hegde S, Greenwood R, Massey E, Davis P. Calculating the required transfusion volume in children. Transfusion. 2007;47(2):212-6.

24. Lv Y, Lau WY, Li Y, Deng J, Han X, Gong $\mathrm{X}$, et al. Hypersplenism: history and current status. Exp Ther Med. 2016;12(4):2377-82.

25. Rachmilewitz EA, Giardina PJ. How I treat thalassemia. Blood. 2011;118(13):3479-88.

26. Neeti Dutt, Meena S, Sushil S. Effectiveness of buffy coat leucoreduced packed red blood cells in decreasing febrile non-hemolytic transfusion reactions in thalassemic patients. Int $\mathbf{J}$ Res Med Sci. 2017 May;5(5):1756-59.

27. Tan KK, Lee WS, Liaw LC, Oh A. A prospective study on the use of leucocyte- filters in reducing blood transfusion reactions in multi-transfused thalassemic children. Singapore Med J. 1993;34:109-11.

28. Devi SAM, Gaikhonlungpou KG. Leukodepletion status of blood products and transfusion reactions in thalassemic patients. J Appl Hematol. 2014;5:29-31.

29. Karen E, King R, Shirey S, Sandra K. Universal leukoreduction decreases the incidence of febrile nonhemolytic transfusion reactions to RBCs. Transfusion. 2004;44:25-9.

30. Kumar H, Gupta PK, Mishra DK, Sarkar RS, Jaiprakash M. Leukodepletion and blood products. Med J Armed Forces India. 2006;62:174-7. 